\title{
ОСОБЕННОСТИ ПСИХОМОТОРНОГО РАЗВИТИЯ ДОШКОЛЬНИКОВ С ОБЩИМ НЕДОРАЗВИТИЕМ РЕЧИ
}

\section{FEATURES OF PSYCHOMOTOR DEVELOPMENT OF PRESCHOOL CHILDREN WITH GENERAL SPEECH UNDERDEVELOPMENT}

\section{S. Arkhipova M. Podshivalova}

Summary: In the materials of the presented article, the technology of organizing and conducting diagnostics of the level of psychomotor development of children of senior preschool age with General speech underdevelopment (according to G.A. Volkova) is considered, and the results of the research are discussed. The article gives a qualitative and quantitative assessment of the General voluntary motor skills, the ability to form certain mimic poses, oral praxis and voluntary motor skills of children's fingers.

Keywords: psychomotorics, psychomotor development, general speech underdevelopment, preschoolers with general speech underdevelopment.
Архипова Светлана Владимировна

К.n.н., дочент, ФГБОУ ВО «Мордовский государственный педагогический университет имени М.Е. Евсевьева»

(2. Саранск)

arhipova.swetlana2011@yandex.ru

Подшивалова Маргарита Сергеевна

ФГБОУ ВО «Мордовский государственный педагогический университет имени М.Е. Евсевьева» (2. Саранск) rita.podshivalova@yandex.ru

Аннотация: В материалах представленной статьи рассматривается технология организации и проведения диагностики уровня психомоторного развития детей старшего дошкольного возраста с общим недоразвитием речи (по Г.А. Волковой), обсуждаются результаты проведенного исследования. В статье дается качественная и количественная оценка общей произвольной моторики, способности произвольного формирования определенных мимических поз, орального праксиса и произвольной моторики пальцев рук детей.

Ключевые слова: психомоторика, психомоторное развитие, общее недоразвитие речи, дошкольники с общим недоразвитием речи.

торику как проявление форм психического поведения в мышечных движениях, отвечающих за гносеологическую и праксеологическую функции, регулирующие работу всех органов чувств человека [8, с. 235].

По мнению В.А. Жмурова, психомоторика - это область психического проявления событий, имеющих отношение к произвольным движениям.

К.К. Платонов считает, что психомоторика - это основной вид объективизации психики в сенсомоторных, идеомоторных, эмоциональных и двигательных реакциях и поступках [5, с. 13].

В.В. Никандров данный термин определяет как разновидность психически обусловленных движений человека, типологически различных в зависимости от строения тела, возраста, пола и т. п.» [7].

Однако представленные выше определения данного понятия позволяют обобщить его основные характеристики и заключить, что психомоторика - это единство двигательного, познавательного и эмоционального ком-

Так, И.М. Сеченов в своих работах трактует психомопсихомоторного развития (Б.Г. Ананьев, В.И. Бехтерев, В.П. Дудьев, А.В. Запорожец, М.М. Кольцова, А.Р. Лурия, И.П. Павлов, И.И. Сеченов, А.А. Ухтомский и др.) позволяет заключить, что на сегодняшний день единого общепринятого определения понятия «психомоторика» не существует.

Исследование выполнено при финансовой поддержке вуза-партнера ФГБОУ ВО «Чувашский государственный педагогический университет им. И. Я. Яковлева» по теме: «Применение коррекционно-развивающих технологий в процессе развития психомоторных функций у дошкольников с ограниченными возможностями здоровья» (№ 35/2020, дата рег:. 16.04.2020). 
понентов, отвечающих за гармоничное развитие личности человека, и его полноценное взаимодействие с окружающим миром [1, с. 34].

Двигательный компонент характеризует отработанные двигательные действия, выполняемые без целенаправленного внимания на их детали. Навык решения той или иной двигательной задачи, основан на многоуровневой координационной структуре, сложившейся в процессе жизненной практики, обучения, тренировки.

Познавательный компонент отвечает за успешность интеллектуального развития ребенка.

Эмоционально-волевая сфера - важный компонент психомоторного развития, оказывающий колоссальное влияние на формирование личности ребенка в целом, начиная с первых дней его жизни [4, с. 217].

Т. Бауэр, Л.Т. Журба, А.В. Запорожец, М.М. Кольцова, Е.М. Мастюкова и др. в своих исследованиях трактуют о том, что развитие психомоторики у детей протекает неравномерно, и может довольно широко отличаться по темпу, но при этом сохранять четкую последовательность в становлении двигательных и психических функций. А так же отмечают, что на начальных этапах онтогенеза психомоторного развития психика и моторика неразрывно взаимосвязаны.

В исследованиях А.А. Леонтьева, А.Р. Лурии, И.П. Павлова и др. подтверждена взаимосвязь общей и речевой моторики. Они отмечают, что развитие мелкой моторики предшествует становлению речи ребёнка.

Поражение центральной нервной системы органического, и, нередко, функционального генеза приводит к различным отклонениям в развитии моторики, а также речи (В.И. Бельтюков, М.О. Гуревич, Л.А. Квинт, В.А Куршев, А.А. Леонтьев, А.Р. Лурия, М.М. Кольцова, Е.М. Мастюкова).

Одним из наиболее распространенных речевых нарушений, встречающихся у детей дошкольного и младшего школьного возраста, является общее недоразвитие речи (далее ОНР).

Данное понятие применяется к такой форме речевого недоразвития, когда нарушается формирование всех компонентов речи: фонетики, лексики, грамматики.

Изучение проблемы психомоторного развития дошкольников с ОНР является значимым в логопедической науке, так как данная речевая патология является достаточно тяжелой и широко распространенной.

Особенности психомоторного развития детей с
ОНР изучаются Ю.Ф. Гаркуша, Г.В. Гуровец, Р.Е. Левиной, С.И. Маевской, Р.И. Мартыновой, Е.Ф. Соботович, О.Н. Усановой, А.Ф. Чернопольской, А.В. Ястребовой и др. В своих исследованиях они указывают, что для данной категории детей характерно запаздывание развития двигательной сферы. Им свойственны нарушения координации движений, замедленная скорость и неловкость их выполнения, неуверенность при выполнении дозированных движений. При выполнении упражнений с пространственно-временной характеристикой, а также серийных комплексов дошкольники с ОНР не воспроизводят всю последовательность элементов двигательного комплекса, пропускают их.

Это объясняется тем, что моторное развитие детей с ОНР и нормотипичных дошкольников проходит неравномерно и значительно отличается по срокам формирования (С.И. Маевская, Е.Ф. Соботович).

Нарушения координации движений - одна из причин затруднений дошкольников в обучении речевой деятельности. Данные положения выдвинуты и доказаны многими учёными (М.О. Гуревич, Л.А. Квинт, М.М. Кольцова, В.А. Куршев, А.А. Леонтьев, А.Р. Лурия, Е.М. Мастюкова) [3; 7].

В исследованиях (М.О. Гуревич, Л.А. Квинт, М.М. Кольцова, В.А. Куршев, А.А. Леонтьев, А.Р. Лурия, Е.М. Мастюкова) показано, что одной из причин затруднений дошкольников в обучении речевой деятельности является нарушения координации движений.

Нарушения развития общей, артикуляционной и тонкой моторики у детей 5-6 лет с ОНР взаимообусловлены. Л.С. Выготский, И.Ю. Горская, П.С. Дворкин, П.В. Карпова, А.А. Леонтьев, А.Р. Лурия в своих работах отмечают, что формирование речи напрямую зависит от двигательной активности ребенка, и в первую очередь от становления и совершенствования координации движений крупной и мелкой моторики. А.В. Запорожец, отмечает, что так же, благодаря точным, динамическим движениям совершенствуется артикуляционный аппарат.

В материалах статьи мы рассматриваем технологию организации и проведения диагностики уровня психомоторного развития детей старшего дошкольного возраста с общим недоразвитием речи (по Г.А. Волковой), анализируем результаты проведенного исследования.

Экспериментальная работа была организована в МДОу «Детский сад № 65 комбинированного вида» и МДОУ «Детский сад № 78 комбинированного вида» г. о. Саранск (Россия). В ней приняли участие воспитанники старших групп компенсирующей направленности в возрасте 5-6 лет, имеющих логопедическое заключение «Локальное поврежденное развитие. Общее недораз- 
витие речи I уровня», «Диффузное поврежденное развитие. Общее недоразвитие речи I уровня», «Парциальная недостаточность когнитивного компонента деятельности. Общее недоразвитие речи II уровня», «Парциальная недостаточность вербального компонента деятельности. Общее недоразвитие речи III уровня».

Для диагностики были применены субтесты, рекомендованные Г.А. Волковой для обследования психомоторики детей старшего дошкольного возраста [2].

Данные субтесты разбиты на 4 серии заданий.

Серия 1. Обследование общей произвольной моторики.

Цель - исследование отдельных компонентов общей произвольной моторики: статической и динамической координации, отчетливости и одновременности движений.

Серия 2. Обследование мимических поз.

Цель - выявление возможности, качества и объема определенных мимических поз.

\section{Серия 3. Обследование орального праксиса.}

Цель - изучение точности, силы, объема, переключаемости движений губ, щек, языка.

Серия 4. Изучение произвольной моторики пальцев рук.

Цель - выявление качества и степени дифференцированности движений тонкой моторики пальцев рук.

В каждой серии представлено по 5 заданий. Выполнение каждой пробы заданий оценивается следующим образом: 1 балл ставится при правильном, четком выполнении того, что требует исследователь; 0,5 балла оценивается частичное, недостаточно четкое выполнение задания; 0,25 балла ставится в случае минимального выполнения или невыполнения упражнения.

По итогам выполнения всех проб, определяется уровень психомоторного развития. Для этого подсчитывается общая сумма набранных баллов, делится на сумму MAX (20) и умножается на $100 \%$. Затем определяется уровень развития: 16-20 баллов (80 \% - $100 \%)$ соответствует высокому уровню; 12-15,8 баллов (60 \% - 79 \%) среднему уровню; менее 12 баллов (ниже $60 \%$ ) - низкому уровню [1].

В ходе первой серии выявлялись особенности общей произвольной моторики дошкольников, особенности статической и динамической координации, четкости и синхронности движений. Двенадцать дошкольников (54,5 \%) выполнили задание на 3,5 балла из 5 возможных. При выполнении заданий у детей отмечались проблемы в различении сторон тела, ведущей руки, нарушение переключения движений, а также неуверенность их выполнения. Шесть воспитанников (27,3%) справились с заданиями на 2,25 балла, так как выполняли их неуверенно, смешивали стороны тела, ведущую руку, медленно переключались с одного движения на другое, испытывали трудности статической координации. Четыре (18,2 \%) дошкольника справились с заданием на 1,75 балла. При выполнении статических упражнений они раскачивались, балансируя туловищем и руками, вставали на всю ступню; при выполнении динамических упражнений дети затруднялись переключать движения, допускали ошибки и неточности в их пространственной организации, пробы выполняли напряженно и неуверенно.

В ходе выполнения заданий второй серии исследовались особенности произвольного формирования некоторых мимических поз. По итогам выполнения четыре дошкольника (18,2 \%) набрали 4 балла из 5 возможных. При выполнении мимических поз они допускали неточности. Восемь обучающихся (36,4 \%) справились с заданием на 3,25 балла, им было трудно изобразить мимические позы «подозрение» и «сомнение». У них отмечалась нечеткая мимическая картина с напряжением мимических мышц, требовалась помощь логопеда. Десять испытуемых (45,4 \%), выполняя задания, набрали 2,5 балла, они нуждались в уточнении инструкции и дополнительном показе мимических поз. Мимика детей вялая, напряженная, мимический рисунок нечеткий. Сложности выполнения или же невыполнение таких мимических поз, как «сомнение», «подозрение», «удивление», «печаль», дети старались компенсировать голосом.

По итогам выполнения заданий третьей серии были выявлены особенности орального праксиса. Четыре ребенка (18,2 \%) справились с заданием на 4 балла из 5 возможных. Выполняя их, они допускали неточности. Шесть испытуемых (27,3 \%) выполнили задания на 3,5 балла. У них отмечались содружественные движения, чрезмерное напряжение мышц. Десять воспитанников (45,4 \%) справились с заданиями на 2,75 балла. У них наблюдались: неточное выполнение упражнений, чрезмерное напряжение мимических мышц, движения языка недостаточного диапазона, содружественные движения. И только два дошкольника (9,1%) справились на 2 балла, у них было отмечено чрезмерное напряжение мышц лица, неточные и неуклюжие движения языка, надувание одной щеки было вовсе недоступно.

В ходе четвертой серии изучались особенности произвольной моторики пальцев рук. Десять дошкольников (45,4 \%) справились с заданием на 3 балла из 5 возможных, так как в их движениях присутствовали напряжен- 
ность и скованность, а также разновременное выполнение проб. Восемь воспитанников (36,4 \%) набрали 2,7 балла. Они выполняли движения неуверенно, допускали неточности, часто сбивались с темпа, нуждались в помощи взрослого. Четверо испытуемых (18,2 \%) справились с упражнениями на 2 балла. У них наблюдались скованность, нарушение темпа (движения выполняли не под счет логопеда, а хаотично и часто сбивались), выполнение некоторых элементов для них оказалось вовсе недоступно, выявлено наличие леворукости. Выполняя задания, дошкольники нуждались в повторном изложении инструкции или демонстрации.

По характеру и успешности выполнения описанных выше заданий всех дошкольников с ОНР мы разделили на две группы.

В первую группу (63,6 \%) вошли обучающиеся со средним уровнем психомоторного развития. Детям этой группы свойственно нечеткое либо частичное выполнение некоторых элементов проб, направленных на выявление особенностей мелкой моторики. При выполнении движений отмечаются: напряженность, скованность пальцев рук и единичные нарушения темпа движений. У испытуемых наблюдаются сложности выполнения общих движений, невозможность удержания поз, неуверенность, зажатость и скованность движений; синкинезии, незначительные изменения объема, силы и точности артикуляционных движений.

Во вторую группу (36,4 \%) вошли дошкольники с ОНР с низким уровнем развития психомоторики. Для обучающихся этой группы характерно грубое нарушение статической и динамической координации движений. Несформированность статической координации отчетливо прослеживается в трудностях сохранения опреде- ленной позы тела или конечности, отмечается тремор. Выявлены нарушения артикуляционного аппарата, выражающиеся в неумении удерживать артикуляционные позы вследствие девиации языка и присутствии чрезмерного напряжения мышц, а также многочисленных недочетах при переключении речевых движений, синкинезиях. Мимическая картина нечетко выраженная. У части испытуемых отмечается напряженная мимика. Владение мелкой моторикой минимальное. Движения рук хаотичны, пальцы рук чрезмерно напряжены, асинхронность выполнения движений на обеих руках. Важно отметить, что при удержании определенно заданной позы воспитанники стараются себе помочь другой рукой.

\section{Выводы}

Анализ результатов, полученных в ходе диагностики уровня психомоторного развития, позволил заключить, что для дошкольников с ОНР наиболее характерны: отклонения в динамической и статической координации от нормы развития; трудности организации движений в пространстве; неточности при выполнении поз из пальцев обеих рук; нарушение темпа выполнения движений; несформированность уклада мышц артикуляционного отдела периферического речевого аппарата. Дети испытывают сложности при выполнении и удержании мимических поз, переключаемости движений губ, щек и языка. Важно отметить, что дошкольникам данной категории очень сложно выполнять задания по словесной инструкции, они нуждаются в ее повторном уточняющем изложении или демонстрации упражнения. Таким образом, данные диагностики свидетельствуют о недостаточном уровне психомоторного развития дошкольников с ОНР, что говорит о необходимости совершенствования коррекционно-развивающей работы в данном направлении.

\section{ЛИТЕРАТУРА}

1. Архипова, С.В. Формирование психомоторных навыков у дошкольников с умственной отсталостью средствами коррекционной ритмики / С.В. Архипова, Т.В. Космачева. // Проблемы современного педагогического образования. Сер: Педагогика и психология: Сборник научных трудов. - Ялта : РИо ГПА, 2018. - Вып. 59. - 4. 3. - С. 33-36.

2. Волкова, Г.А. Методика психолого-логопедического обследования детей с нарушениями речи. Вопросы дифференциальной диагностики: учебно-методическое пособие / Г.А. Волкова. - Санкт-Петербург: Детство-Пресс, 2008. - 133 c. URL: https://search.rsl.ru/ru/record/01004099163 (дата обращения: 02.04.2020). -ISBN 5-89814-207-X

3. Волкова, Л.С. Логопедическая ритмика / Л. С. Волкова. - Москва: Владос, 2008. - 680 с. - ISBN 5-691-00936-2.

4. Ильин, Е.П. Психомоторная организация человека / Е.П. Ильин. - Санкт-Петербург: Питер - 2003. - 384 с. - ISBN 5-94723-491-2.

5. Коноваленко, С.В. Развитие психофизиологической базы речи у детей дошкольного возраста с нарушениями развития / С.В. Коноваленко, М.И. Кременецкая. - Санкт-Петербург: Детство-Пресс, 2017. - 126 с. - ISBN 978-5-906797-51-3.

6. Морозова, И.С. Психомоторное развитие дошкольников: цикл занятий / И.С. Морозова, 0.М. Гарусова. - Москва: Национальный книжный центр, 2016 96 c. - ISBN 978-5-4441-0117-9.

7. Никандров, В.В. Психомоторика: учебное пособие / В.В. Никандров. - Санкт-Петербург: Речь, 2004. - 104 с. - URL: http://lib.mgppu.ru/0pacUnicode/app/ webroot/index.php?url=/notices/index/IdNotice:238469/Source:default (дата обращения : 03.04.2020). - ISBN 5-9268-0141-9

(c) Архипова Светлана Владимировна (arhipova.swetlana2011@yandex.ru), Подшивалова Маргарита Cepгеeвна (rita.podshivalova@yandex.ru). 